геноструктурный анализ возможностями спектроскопии с высоким временным разрешением, связанной, в том числе, с аттосекундной спектроскопией и аттосекундной метрологией.

В настоящей работе рассмотрено влияние присутствия дефектов в наноструктурированных мишенях на интерференционные спектры при переизлучении аттосекундных импульсов электромагнитного поля. Получены общие выражения для расчетов спектральных распределений при переизлучении одномерными, двухмерными и трехмерными многоатомными наносистемами, составленными из одинаковых сложных атомов с дефектами типа изгибов, вакансий и разрывов. В качестве примеров, допускающих простое аналитическое представление, проведены расчеты изменений интерференционных спектров: линейной цепочкой с удаленными несколькими атомами (цепочка с разрывами), линейной цепочкой с изгибом. Развито обобщение на двух- и трехмерные наносистемы. Предложенный подход непосредственно может быть распространен на более общие типы дефектов. В рассматриваемых нами случаях считается, что длительность аттосекундных импульсов значительно меньше характерного атомного времени. Так что поле аттосекундного импульса рассматривается как внезапное возмущение [2-3]. После действия внезапного возмущения, возбужденные атомы мишени могут релаксировать. Спектры переизлучения и спектры, испускаемые при релаксации строго разделены по времени и могут быть идентифицированы по схеме совпадений с аттосекундным импульсом.

1. John M. Cowley Diffraction Physics (North-Holland, Amsterdam), 1975.

2. Макаров Д.Н., Матвеев В.И. ЖЭТФ, 144, 905 (2013).

3. Макаров Д.Н., Матвеев В.И. Оптика и спектроскопия, 116, 179 (2014).

\title{
EFFECT OF POLYLACTIC ACID CRYSTALLINITY ON ITS ELECTRET PROPERTIES
}

\author{
Guzhova A.A.. , Galikhanov M.F., Kuznetsova N.V., Petrov V.A., Khairullin R.Z. \\ Kazan National Research Technological university, Kazan, Russia \\ *E-mail: alina_guzhova@mail.ru
}

Nowadays application of corona discharge to make electret materials of polar polymers (including polylactic acid) attracts interest of scientists. This method is characterized by simple equipment, high speed of the process, and relatively uniform charge distribution on the material surface. The method is based on injection of charge carriers (electrons and ions), formed by electric discharge in air gap between corona electrode and dielectric material, into the bulk of the dielectric and their capture by energy traps (surface and volume ones). Chemically-active impurities, polymer structure defects, interface boundary, free volume of the polymer, etc. can act as 
charge traps [1]. Roles played by different types of the traps in electret state stability in polymer materials have been imperfectly studied. Particularly, correlation between electret properties and degree of crystallinity is not clear. There are just a few reports devoted to effects of structural characteristics of polymers on polarizability [2, 3].

The aim of the paper was to study relation between supramolecular structure of the semicrystalline polymer and its electret properties.

The object of research was polylactic acid (PLA) produced by Zhejiang Hisun Biomaterials Co., Ltd. PLA films $200 \mu \mathrm{m}$ thick were manufactured by compression molding at different cooling rate. Samples polarization was performed in negative corona discharge. Surface potential $V_{s}$, effective surface charge density $\sigma_{e f}$ and electric field strength $E$ of the films were measured by electrostatic fieldmeter IPEP-1 Multipurpose X-ray diffraction system "Rigaku Ultima IV" was used for XRD analysis of the samples.

Various cooling rate of the samples allows changing crystallization rate of the polylactic acid and, consequently, its degree of crystallinity. Comparison of electret properties of the polymer films at $14^{\text {th }}$ day and their structural parameters showed samples with higher crystallinity to have more stable electret state (see table). This fact can be explained by increase of interface boundary between amorphous and crystalline regions that can act as potential energy trap for injected charge carriers.

Degree of crystallinity and electret properties of polylactic acid films

\begin{tabular}{|c|c|c|c|}
\hline PLA degree of crystallinity, $\%$ & $\boldsymbol{V}_{\boldsymbol{s I} \mathbf{4}}, \mathbf{V}$ & $\boldsymbol{\sigma}_{\text {ef } \mathbf{4} \boldsymbol{}}, \boldsymbol{\mu} \mathbf{C} / \mathbf{m}^{\mathbf{2}}$ & $\boldsymbol{E}_{\mathbf{1 4}}, \mathbf{k V} / \mathbf{m}$ \\
\hline 0 & 77 & 0.042 & 4.8 \\
\hline 27.17 & 100 & 0.048 & 5.0 \\
\hline 43.86 & 252 & 0.101 & 15.5 \\
\hline
\end{tabular}

Increase of the electret properties in the samples with higher crystallinity also may result from change in electrical conductivity of the films that determines polymer electret stability. However, there was no substantial difference in specific volume conductivity values of the samples that exceeded experimental error. On the other hand, growth of the interface boundary between phases with different electrical conductivity increases contribution of Maxwell-Wagner effect in total polarizability of the polylactic acid i.e. raises portion of charge carriers concentrated at amorphouscrystalline interface.

Obtained data can be applied for solving practical problems of increasing electret properties of a polar polymer.

1. Sessler G.M., Gerhard-Multhaupt, R. (editors). Electrets. Third edition in two volumes, California, USA: Laplacian Press, Morgan Hill (1998/1999). 472/360 p.

2. Behrendt N., Mohmeyer N. et al., J. of Appl. Polym. Sci., 99 (2006)

3. Thyssen A., Almdal K., Thomsen E.V., Proc. 15th International Symposium on Electrets, ISE 2014, Baltimore, USA (2014) 